\title{
Never a rose without a prick: pseudohyperglycemia when administering high-dose intravenous vitamin C
}

\author{
Yongli Zhang and Wei Huang ${ }^{*}$ (D)
}

Given its multiple biological actions, high-dose vitamin $\mathrm{C}$ has been considered an encouraging treatment against septic shock. Although evidence for metabolic resuscitation strategies with ascorbic acid, hydrocortisone, and thiamine is accumulating $[1,2]$, there are still many unresolved issues that need to be addressed. One is pseudohyperglycemia, induced by interference of ascorbic acid with point-of-care (POC) glucose measurements, which might be neglected by most physicians and easily provoke intervention with insulin and result in potential life-threatening hypoglycemia.

Briefly, in contrast to laboratory-based standard serum glucose measurement by spectrophotometric techniques using the hexokinase method, finger-stick blood glucose (FSBG) meters, or self-monitoring blood glucose (SMBG) devices, routinely utilized in ICU, rely on glucose oxidase or glucose dehydrogenase (GDH) methods [3]. The enzymatic reaction produces an electrical current, the strength of which proportionally represents the level of blood glucose. When ascorbic acid is administered, it is oxidized at the surface of the monitor, resulting in the release of an electron and negative charge. Therefore, highdosage intravenous ascorbic acid could yield false hyperglycemia measured by POC devices, which has been documented in burn patients receiving intravenous vitamin $\mathrm{C}$ infusions $(66 \mathrm{mg} / \mathrm{kg} / \mathrm{h})$ [4]. Apart from vitamin C, dopamine, acetaminophen, and icodextrin could also interfere with POC testing.

However, it needs to be mentioned that the inaccuracy of POC devices is likely to be related to plasma vitamin $\mathrm{C}$ concentrations. Compared with the regimen of the

* Correspondence: huangwei@dmu.edu.cn

Department of Critical Care Medicine, The First Affiliated Hospital of Dalian Medical University, 222 Zhongshan Road, Dalian 116012, LiaoNing Province, China

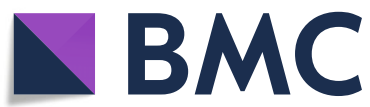

burn patients [4], the dose used in sepsis patients [1] was substantially lower ( $14 \mathrm{~g} / \mathrm{d}$ for a $70-\mathrm{kg}$ person), without unexpected adverse events. In addition, a retrospective study [5] suggested that most sepsis patients receiving vitamin $C(9 \mathrm{~g} / \mathrm{d})$ could be managed with POC testing without major clinical impact. In the future, prospective studies should be performed to analyze the association between vitamin $\mathrm{C}$ dosage and plasma concentrations, the deviation of POC glucose measurements and spectrophotometric measurement, and clinical symptoms of hypoglycemia. It is also necessary to explore the impacts of concomitant confounders such as renal function and use of vasopressors, because renal dysfunction may lead to higher vitamin $\mathrm{C}$ plasma concentrations, and vasopressors may interfere with $\mathrm{POC}$ measurements.

In conclusion, when initiating high-dose vitamin $\mathrm{C}$, physicians should be aware of the potential consequences of pseudohyperglycemia if employing POC devices for glucose monitoring. In this setting, the absorbance-photometric-based laboratory glucose tests rather than electrochemical detection should be used.

\section{Acknowledgments \\ Not applicable.}

\section{Authors' contributions}

All authors drafted and revised the manuscript. All authors read and approved the final manuscript.

\section{Funding}

Not applicable.

Availability of data and materials Not applicable.

Ethics approval and consent to participate Not applicable.

( The Author(s). 2020 Open Access This article is licensed under a Creative Commons Attribution 4.0 International License, which permits use, sharing, adaptation, distribution and reproduction in any medium or format, as long as you give appropriate credit to the original author(s) and the source, provide a link to the Creative Commons licence, and indicate if changes were made. The images or other third party material in this article are included in the article's Creative Commons licence, unless indicated otherwise in a credit line to the material. If material is not included in the article's Creative Commons licence and your intended use is not permitted by statutory regulation or exceeds the permitted use, you will need to obtain permission directly from the copyright holder. To view a copy of this licence, visit http://creativecommons.org/licenses/by/4.0/ The Creative Commons Public Domain Dedication waiver (http://creativecommons.org/publicdomain/zero/1.0/) applies to the data made available in this article, unless otherwise stated in a credit line to the data. 


\section{Consent for publication}

Not applicable.

\section{Competing interests}

The authors declare that they have no competing interests.

Received: 7 February 2020 Accepted: 14 May 2020

Published online: 24 May 2020

\section{References}

1. Fowler AA 3rd, Truwit JD, Hite RD, Morris PE, DeWilde C, Priday A, Fisher B, Thacker LR 2nd, Natarajan R, Brophy DF, et al. Effect of vitamin C infusion on organ failure and biomarkers of inflammation and vascular injury in patients with sepsis and severe acute respiratory failure: the CITRIS-ALI randomized clinical trial. JAMA. 2019:322:1261-70.

2. Carr AC. Vitamin C administration in the critically ill: a summary of recent meta-analyses. Crit Care. 2019;30(23):265.

3. Tang Z, Du X, Louie RF, Kost GJ. Effects of drugs on glucose measurements with handheld glucose meters and a portable glucose analyzer. Am J Clin Pathol. 2000;113:75-86.

4. Kahn SA, Lentz CW. Fictitious hyperglycemia: point-of-care glucose measurement is inaccurate during high-dose vitamin $\mathrm{C}$ infusion for burn shock resuscitation. J Burn Care Res. 2015;36(2):e67-71.

5. Howell AP, Parrett JL. Malcom DR3. impact of high-dose intravenous vitamin C for treatment of sepsis on point-of-care blood glucose readings. J Diabetes Sci Technol. 2019. https://doi.org/10.1177/1932296819889638 [Epub ahead of print].

\section{Publisher's Note}

Springer Nature remains neutral with regard to jurisdictional claims in published maps and institutional affiliations. 